1966

\title{
Constitutional Ramifications of the Police Lineup
}

Thomas Edward Byrne

Marc B. Kaplin

Walter John Taggart

Follow this and additional works at: https://digitalcommons.law.villanova.edu/vlr

Part of the Constitutional Law Commons, Criminal Law Commons, Criminal Procedure Commons, and the Evidence Commons

\section{Recommended Citation}

Thomas E. Byrne, Marc B. Kaplin \& Walter J. Taggart, Constitutional Ramifications of the Police Lineup, 12 Vill. L. Rev. 135 (1966).

Available at: https://digitalcommons.law.villanova.edu/vlr/vol12/iss1/3

This Comment is brought to you for free and open access by Villanova University Charles Widger School of Law Digital Repository. It has been accepted for inclusion in Villanova Law Review by an authorized editor of Villanova University Charles Widger School of Law Digital Repository. 


\section{COMMENTS}

\section{CONSTITUTIONAL RAMIFICATIONS OF THE POLICE LINEUP}

\section{INTRODUCTION}

A major revaluation of the constitutional guarantees of the Bill of Rights and the fourteenth amendment has taken place in the past decade with regard to the rights of the criminal defendant, and many police practices, once generally accepted, have been held to be unconstitutional. It is entirely possible that further changes may be forthcoming.

This comment was conceived in order to explore the common police lineup, with a view toward predicting the outcome of possible constitutional challenges to lineup procedures and incorporating in a Model Lineup Procedure those steps which, in light of our projections, are necessary to protect the rights of the individual and at the same time preserve the lineup as an effective tool for law enforcement.

\section{Typical Lineup Procedures ${ }^{1}$}

The lineup of criminal suspects is a widely used investigative technique. In practice it is a more or less formal procedure whereby complaining witnesses view persons suspected of committing crimes. Each suspect is "lined up" as part of a group which may include other suspects in police custody, prisoners, or police officers dressed in civilian clothing. In some jurisdictions, suspects' counsel are permitted to be present during the lineup, while in others, counsel are not admitted, even when a suspect requests that his attorney be present.

In some cities, lineups are held in specially-designed auditoriums. These facilities usually include a stage equipped with theatrical lighting on which participating suspects take their places. In Philadelphia, a glass partition divides the auditorium section from the stage, and suspects can neither see the persons who are viewing them nor hear their conversation. Microphones and speakers allow the voices of the suspects to be heard by the audience.

1. Much of the information for this survey of lineup procedures was contained in a memorandum prepared by the Defenders Association of Philadelphia in response to a request by the Third Circuit Court of Appeals in Rigney v. Hendrick, 355 F.2d 710 (3d Cir. 1965), cert. denied, 384 U.S. 975 (1966). Practices in ten major American cities were considered in the preparation of this memorandum. See also Wade v. United States, 358 F.2d 557 (5th Cir. 1966); People v. Gilbert, 63 Cal. 2d 690, 408 P.2d 365, 47 Cal. Rptr. 909 (1965), cert. granted sub nom. Gilbert v. California, 384 U.S. 985 (1966). 
In contrast to the formal lineup procedures are the lineups which are conducted in local police stations by bringing the suspect, along with several other persons, into a room where he is directly confronted by the complaining witness. During a typical lineup it is common for the police to require suspects to move about or to assume a stance which may relate to an offense. Suspects may also be required to hold certain objects, such as a gun or flashlight, or to wear various articles of clothing which were worn by the culprit during the commission of the offense being investigated. The quality of the voice of the suspect may be crucial in the investigation of certain crimes. In certain cases each person in the lineup may be required to repeat the exact words which a witness heard used by the culprit. In other instances only a general voice sample is elicited.

Lineups can also be differentiated according to the procedural stage at which the police use this investigative technique, vis-a-vis a particular suspect. Three classifications are apparent: lineups of suspects who have been arrested, but who have not yet been indicted; lineups of suspects who are held in the custody of the authorities pending trial; and voluntary appearances by suspects who have been released on bail.

Certain aspects of the common lineup procedures briefly sketched above suggest the possibility of serious constitutional questions arising in the near future. The following discussion is an attempt to define these questions and forecast their probable outcome.

\section{The Lineup and the Privilege Against Self-Incrimination}

The United States Supreme Court has not considered the question of whether a police lineup is per se violative of the fifth amendment protection against self-incrimination, ${ }^{2}$ although it has been declared constitutional in cursory examinations by a few lower courts ${ }^{3}$ prior to the recent landmark decisions in the area of criminal procedure. ${ }^{4}$ These lower court

2. "No person shall be . . . compelled in any criminal case to be a witness against himself ..." U.S. Const. amend. V. See generally InbaU, SELF-InCRIMINATION (1950); MAYers, Shall We AMEND THE FIFTH AMENDMENT? (1959); MCCormick, Evidence 252-90 (1954); 3 Wharton, Criminal Evidence 12-63 (12th ed. 1955); 8 WIGMORE, EVIDENCE $\$ \S 2250-84$ (MCNaughton Rev. 1961) [hereinafter cited as WIGMORE] ; Corwin, The Supreme Court's Construction of the Self-Incrimination Clause, 29 MicH. L. REv. 1, 191 (1930); Pittman, The Colonial and Constitutional History of the Privilege Against Self-Incrimination in America, 21 VA. L. REv. 763 (1935).

3. The following quotation exemplifies the cursory treatment given the lineup by the lower courts: "We find no reason to express a contrary conclusion so far as relates to the ordinary police lineup which is carried out under conditions which permit the greatest objectivity of viewing the accused with others who are exhibited with him." Wade v. United States, 358 F.2d 557, 559 (5th Cir.), cert. granted, 35 U.S.L. WEEK 3083 (Sept. 13, 1966). Other cases illustrating this same type of treatment are United States v. Denno, 355 F.2d 731 (2d Cir.), cert. granted, 35 U.S.L. WEEK 3050 (July 26, 1966); Caldwell v. United States, 338 F.2d 385 (8th Cir. 1964); People v. Lopez, 60 Cal. 2d 223, 384 P.2d 16, 32 Cal. Rptr. 424 (1963); Meriwether v. State, 63 Ga. App. 667, 11 S.E.2d 816 (1940).

4. In this regard, note the following statement of the Court in Miranda v. Arizona, 384 U.S. 436, 467 (1966) :

Today, then, there can be no doubt that the Fifth Amendment privilege is available outside of criminal court proceedings and serves to protect persons in all 
decisions considered only the general constitutionality of the lineup, without discussing the particular procedures employed by various enforcement agencies. ${ }^{5}$ Their value to this discussion is therefore extremely limited.

Judicial investigation of the privilege against self-incrimination in areas analogous to the lineup, however, has been more thorough. There are many cases dealing with the propriety of the use of finger prints, blood tests, handwriting samples and the like as investigative tools. ${ }^{6}$ An examination of these decisions is necessary to a definition of the standards which courts have employed in applying the privilege.

\section{A. The Fifth Amendment Standards}

The opinion of Mr. Justice Holmes in Holt v. United States ${ }^{7}$ is the authority relied upon by many of the opinions dealing with areas analogous to the lineup. In that case the defendant in a murder trial was compelled to try on a blouse which allegedly belonged to him. An attempt was made to exclude the testimony of a witness to this exhibition on the ground that the proceeding violated the defendant's privilege against self-incrimination. In refuting this contention Justice Holmes asserted that:

[T] he prohibition of compelling a man in a criminal court to be witness against himself is a prohibition of the use of physical or moral compulsion to extort communications from him, not an exclusion of his body as evidence when it may be material. The objection in principle would forbid a jury to look at a prisoner and compare his features with a photograph in proof. ${ }^{8}$

In 1964, more than 50 years after the Holt decision, the Eighth Circuit Court of Appeals declared that the fifth amendment rights of the accused were not violated by the use of a lineup during the investigative stage in order to permit witnesses who had previously identified the defendant's photograph to view him personally. Judge Mehaffy stated that:

The mere viewing of a suspect under arrest by eye-witnesses does not violate the constitutional privilege [self-incrimination] because the prisoner is not required to be an unwilling witness against himself. There is a distinction between bodily view and requiring an accused to testify against himself. ${ }^{9}$

settings in which their freedom of action is curtailed from being compelled to incriminate themselves. We have concluded that without proper safeguards the process of incustody interrogation of persons suspected or accused of crime contains inherently compelling pressures which work to undermine the individual's will to resist and to compel him to speak where he would not otherwise do so freely. In order to combat these pressures and to permit a full opportunity to exercise the privilege against self-incrimination, the accused must be adequately and effectively apprised of his rights and the exercise of those rights must be fully honored.

See Schmerber v. California, 384 U.S. 757 (1966); Escobedo v. Illinois, 378 U.S. 478 (1964).

5. See Caldwell v. United States, 338 F.2d 385 (8th Cir. 1964).

6. For a compilation of cases in these areas see 8 WIGMORE $\$ 2265$.

7. 218 U.S. $245(1910)$.

8. Id. at 252-53.

9. Caldwell v. United States, 338 F.2d 385, 389 (8th Cir. 1964). 
The use of the defendant's fingerprints, palmprints, or footprints has been universally held not to violate the privilege against self-incrimination when these prints are taken voluntarily. ${ }^{10}$ In most cases the same result is reached even though the prints have been obtained through coercion. ${ }^{11}$

In addition to the reasoning advanced in the physical exhibition decisions, it is evident that the practical necessities of law enforcement have had an important influence on the courts. In United States v. Kelly the Second Circuit Court of Appeals asserted that it preferred "to rest its decision upon the general right of the authorities charged with the enforcement of the criminal law to employ fingerprinting as an appropriate means to identify criminals and detect crime."12

The question of the admissibility of evidence obtained in a physical examination ${ }^{13}$ has been raised a number of times in the federal courts. An analysis of the decisions in these cases reveals a logical outgrowth of the doctrine laid down in the Holt decision. ${ }^{14}$ In McFarland v. United States ${ }^{15}$ the defendant submitted to a physical examination pursuant to a military order, and evidence was admitted showing that blood found on his body indicated that he was the assailant in a rape and murder. The court quite broadly stated that, "out of court as well as in court, his body may be examined with or without his consent."10 In United States $v$. Nesmith ${ }^{17}$ defendant was indicted for manslaughter arising out of an automobile accident. A motion to suppress evidence of a chemical analysis of a urine specimen furnished by him at the direction of a law enforcement officer to determine whether he was under the influence of alcohol at the time of the accident was denied. After an analysis of the federal cases in point, the court concluded that "the privilege against self-incrimination is limited to the giving of oral testimony. It does not extend to the use of the defendant's body as physical or real evidence."18

The conclusion reached in Nesmith was expanded, at least implicitly, by the Supreme Court in Schmerber v. California, ${ }^{19}$ a case dealing with the use of blood tests. In Schmerber, a motion to exclude from evidence an analysis of defendant's blood, taken over his objection shortly after his arrest on drunken driving charges, was denied. Mr. Justice Brennan,

10. E.g., United States v. Iacullo, 226 F.2d 788 (7th Cir. 1955) ; People v. Jones, 112 Cal. App. 68, 296 Pac. 317 (1931) ; People v. Sallow, 100 Misc. 447, 165 N.Y.S. 915 (Gen. Sess. 1917); see UnIFOrM Rules of Evidence 23(3), 25(b) ; MODEL CoDE, OF EvIDENCE rule 205 (a) (1942). See generally Annot., 28 A.L.R.2d 1115 (1951); 2 Wharton's Criminal Evidence $\$ 664$ (12th ed. 1955); 8 Wigmore $\$ \S 2263,2265$.

11. E.g., United States v. Kelly, 55 F.2d 67 (2d Cir. 1932) ; State v. Rogers, 233

N.C. 390,64 S.E.2d 572 (1951). See generally Annot., 28 A.L.R.2d 1115 (1953).

12. United States v. Kelly, 55 F.2d 67, 70 (2d Cir. 1932).

13. See generally 8 Wigmore $§ 2265$; Annot., 25 A.L.R.2d 1407 (1952).

14. See note 7 supra and accompanying text.

15. 150 F.2d 593 (D.C. Cir. 1945).

16. Id. at 594 .

17. 121 F. Supp. 758 (D.D.C. 1954).

18. Id. at 762 .

19. 384 U.S. 757 (1966). 
after reaffirming the Court's holding in Boyd $v$. United States, ${ }^{20}$ asserted that the Court, in admitting the blood test evidence, was not adopting as an "ironbound rule" Professor Wigmore's contention that the privilege against self-incrimination extends only to testimonial evidence elicited through compulsion, and not to real or physical facts elicited in a like manner : 21

The distinction which has emerged, often expressed in different ways, is that the privilege is a bar against compelling "communications" or "testimony," but that compulsion which makes a suspect or accused the source of "real or physical evidence" does not violate it.

Although we agree that this distinction is a helpful framework for analysis, we are not to be understood to agree with past application in all instances. . . . In the present case, however, no such problem of application is presented. Not even a shadow of testimonial compulsion upon or enforced communication by the accused was involved either in the extraction or in the chemical analysis. Petitioner's testimonial capacities were in no way implicated; indeed, his participation, except as a donor, was irrelevant to the results of the test, which depend on chemical analysis and on that alone. Since the blood test evidence, although an incriminating product of compulsion, was neither petitioner's testimony nor evidence relating to some communicative act or writing by the petitioner, it was not inadmissible on privelege grounds. ${ }^{22}$

The Schmerber opinion raises immediate questions with regard to the situations in which problems of application may arise in the lineup area, and the rule of law that will be employed in arriving at solutions to these problems.

While the Wigmore analysis of the fifth amendment has been generally accepted, its application has not been universal. A second interpretation of the amendment draws the line "between enforced passivity on the part of the accused and enforced activity on his part. Submission may be compelled but not active cooperation, for then he is made 'to be a witness' or 'to give evidence'."23 The practical effect of the varying interpretations of the privilege against self-incrimination becomes evident when the problems of compulsory ${ }^{24}$ handwriting exemplars and the use of voice exhibitions for identification purposes are considered.25 If Wig-

20. 116 U.S. 616 (1886). Compulsory production of one's private papers is the same as compelling him to be a witness against himself.

21. The rule as stated by Wigmore is to the effect that "the privilege is limited to testimonial disclosures. It was directed at the employment of legal process to extract from the person's own lips an admission of guilt which would thus take the place of other evidence." Schmerber v. California, 384 U.S. 757, 763 n.7 (1966) (quoting 8 WIGMORE $\$ 2263$ ).

22. Id. at 764 .

23. MCCormick, Evidence $\S 126$, at 265 (1954). See 4 Jones, EVIdENCE $\S 857$ (5th ed. 1958) ; MAGUIRE, EVIDENCE OF GUILT $\$ 2.04$ at 31 (1959).

24. No problem of self-incrimination arises when these forms of evidence are given voluntarily or the privilege is considered to have been waived. See cases collected in WIGMORE \& $2265 \mathrm{nn} .9$ \& 10.

25. For a more detailed examination of these two areas, see Weintraub, Voice Identification, Writing Exemplars and the Privilege Against Self-Incrimination, 10 VAND. L. REv. 485 (1957) ; Annot., 16 A.L.R.2d 1322 (1948). 
more's dichotomy is employed, the conclusion is inevitable that handwriting is purely physical evidence. "It differs very little in principle from a fingerprint impression secured by compulsion for purposes of comparison with a fingerprint found at the scene of a crime."20 The active-passive rationale would lead to the conclusion that the individual has become active and as such has been forced to participate in his own prosecution. This analysis has been employed in the few decisions passing directly on the constitutionality of compelling a person to execute a handwriting exemplar. ${ }^{27}$ But no case has been found which categorically sanctions the compulsion as constitutional. There are, however, a number of federal ${ }^{28}$ and state $^{29}$ decisions which infer that the evidence obtained would be admissible. The Supreme Court in the Schmerber decision states that "both federal and state courts have usually held that it offers no protection against compulsion to submit to fingerprinting, photographing, or measurements, to write or speak for identification."30 (Emphasis added.)

Application of these two different views of the extent of the privilege to compulsory voice utterances for identification purposes leads to conclusions similar to those reached in their application to handwriting exemplars. Under the Wigmore doctrine the utterance merely would be a physical fact, while under the active-passive doctrine the statement would be violative of the fifth amendment since the defendant has become active in his own prosecution.

The use of voice identifications, however, presents several problems which up to this point have not been at issue where handwriting exemplars were involved. These problems are due in large part to the fact that, historically, there has been a certain "magical air" surrounding incriminating evidence emanating from the spoken word which is not apparent when other types of evidence are elicited from the accused. An examination of the application of the privilege against self-incrimination reveals that its initial purpose was to protect a citizen from incriminating himself through testimonial oaths, and that vocal utterances by the defendant have been the means of self-incrimination which have run deepest in opposition to the fabric of the privilege. ${ }^{31}$

But while most courts would readily admit identifications based on inane statements uttered by the accused, great difficulties have been encountered in securing the admission of an identification where the accused has been compelled to speak the exact words used in the crime. The Texas

26. INBAU, SELF-INCRIMINATION, supra note 2 at 46.

27. United States v. Eggers, 3 U.S.C.M.A. 191, 11 C.M.R. 191 (1953) ; United States v. Rosato, 3 U.S.C.M.A. 143, 11 C.M.R. 143 (1953); Beltran v. Samson and Jose, 53 Phil. Is. 570 (1929).

28. E.g., United States v. Chibbaro, 361 F.2d 365 (3d Cir. 1966); Stanfield v.

United States, 350 F.2d 518 (10th Cir. 1965); Bryant v. United States, 244 F.2d 411, 412 n.4 (5th Cir. 1957); Shelton v. United States, 205 F.2d 806, 814 (5th Cir. 1953); Hartzell v. United States, 72 F.2d 569, 586 (8th Cir. 1934).

29. E.g., People v. Matteson, 61 Cal. 2d 466, 393 P.2d 161, 39 Cal. Rptr. 1 (1964);

People v. Harper, 115 Cal. App. 2d 776, 252 P.2d 950 (1953).

30. Schmerber v. California, 384 U.S. 757, 764 (1966).

31. See WIGMORE $\$ \S 2250-51$. 
and South Carolina courts, adopting the active-passive test, have held that the privilege applies where the evidence, has been "produced by the accused," while the New Jersey and New Mexico courts have chosen in recent decisions to apply the Wigmore analysis and admit such evidence. $^{32}$ There have been no federal cases dealing directly with the constitutionality of compulsory voice identification. The Supreme Court has left the door open to either interpretation of the privilege (testimonial compulsion and real or physical facts versus the active-passive distinction) in the Schmerber opinion by expressly refusing to accept Wigmore's analysis in all circumstances, ${ }^{33}$ yet accepting it in the particular factual situation presented.

Although there appears to be little difference between requiring the exact words of the crime to be spoken (once it is assumed that compulsion to speak for identification is not a violation of the privilege) and requiring the exact clothes worn by the perpetrator of the crime to be worn in a physical exhibition by the defendant (once the compulsion to exhibit has been found to be nonviolative), this difference in fact, when coupled with employment of the active-passive distinction and the inherent distaste of the fifth amendment for oral disclosures, may offer the Court a cut-off point. While this result would not be in accord with the pervasive nature of the Schmerber opinion, it would be in line with the liberal opinions of the Court in other areas of criminal procedure. ${ }^{34}$

It is evident from the foregoing investigation that certain basic criteria have been used by the courts in deciding what procedures and evidentiary material fall within the protection of the fifth amendment proscription against compulsory self-incrimination. Essentially, these criteria are: (1) whether logically and historically the procedure is a legitimate exercise by the police of their right and duty to investigate and prosecute crime $;^{35}$ and (2) whether the procedure merely compels the defendant to convey real or physical evidence or employs testimonial compulsion. In certain instances another line of decisions which distinguishes between enforced passivity and activity on the part of the accused may be employed.

\section{B. Application of Fifth Amendment Standards to the Lineup}

When the standards that have evolved under the fifth amendment are applied to certain specific practices which are, or may be, used during a lineup, a sliding-scale type of analysis is inevitable. At one pole is the

32. Compare State v. Taylor, 213 S.C. 330, 49 S.E.2d 289 (1948), and Beachem v. State, 144 Tex. Crim. 272,162 S.W.2d 706 (1942), with State v. King, 44 N.J. 346, 209 A.2d 110 (1965), and State v. Ramirez, 76 N.M. 72, 412 P.2d 246 (1966). See also Annot., 16 A.L.R.2d 1322 (1948), and INBAU, supra note 26 , at 42,49 .

33. Schmerber v. California, 384 U.S. 757, 764-65 (1966).

34. E.g., Miranda v. Arizona, 384 U.S. 436 (1966); Escobedo v. Illinois, 378 U.S. 478 (1964).

35. E.g., United States v. Kelly, 55 F.2d 67, 70 (2d Cir. 1932) ; Shaffer v. United States, 24 App. D.C. 417, 426 (1904), cert. denied, 196 U.S. 639 (1905). 
practice of dressing the defendant in clothing similar or identical to that used in the crime. Clothing may include anything from a mere shirt or hat to the exact apparel allegedly worn by the assailant. It is submitted that this practice is not within the protection of the privilege since it could not be included in either of the prevailing interpretations. This is because neither testimonial compulsion nor active participation is elicited.

Physical acts by the accused may include the mere assumption of a position or particular pose, or the performance of some overt act which would aid in the effort to either positively or negatively identify him as the assailant. This type of act would be in the nature of a re-creation of the acts of the crime. Since there is obviously no testimonial compulsion evident in the former situation, it would be permissible under the Wigmore approach. It may be argued, with probable success, that even under the active-passive approach the accused could be made to submit to a certain pose without his active participation. As overt physical acts are compelled, the result tends to move toward the opposite pole. Compulsion would be permissible under one analysis, the testimonial compulsion test, and inadmissible under the other, since the defendant would be actively participating in his own prosecution. However, in light of the Supreme Court's approach to the use of blood tests in Schmerber, this type of activity should receive judicial sanction as a proper investigative technique without any trace of traditional testimonial compulsion.

A concluding area appears to come closest to the opposite pole. This area involves compelling suspects to speak inane words or the exact words used in the crime for purposes of identification. Evidence of identification through the use of inane statements would probably be admissible, even though it would be suppressed under the active-passive approach. While the spoken word is closest to the protection afforded by the fifth amendment, the inane statement lacks the characteristics which would classify it as testimonial in nature. ${ }^{36}$ Furthermore, the practical necessity of police identification when the assailant is heard but not seen is so overwhelming as to make its exclusion almost unthinkable. A particularly difficult problem arises where the accused is compelled to utter the exact words used in the crime. The split of authority in the state courts and the lack of any federal decision on this issue was previously noted, and the Supreme Court's failure in Schmerber to adopt the Wigmore approach as the applicable rule in all situations leaves its position in doubt. However, it would seem that, in view of the Schmerber decision, exclusion would have to be considered almost a reversal in approach, whereas the Court's approval might be considered no more than the next logical step in this area.

36. Weintraub suggests that the privilege may only be invoked to protect statements which an accused person is compelled to make, and upon which reliance is placed concerning the veracity of the statement. In other words, only where the accused is able to control the statement as a means of transmitting ideas. Where an inane statement is elicited, reliance is not placed upon what the accused says, but only that it is his normal voice, a fact which may be substantiated by other testimony. Weintraub, supra note 25 , at $508-09$. 
Those who would press for approval of the procedure would assert initially that there is no historical justification for exclusion of the identification. The privilege is a proscription against compelling a man to do those things which a witness would traditionally do - to give oral testimony as evidence of the facts stated and to produce documents and other relevant objects in court. Since there is no reliance placed upon the veracity of the defendant's statement, except with regard to his voice, there is no testimony actually given; the oral statement is used only for identification purposes. The fact that the exact words are being used means nothing in this context. Secondly, it would be argued that when the procedure used is examined in light of the underlying purpose of the privilege, there is again no reason for excluding it. The basic reason for justifying the availability of the privilege to the accused is professed by Wigmore:

The real objection is that any system of administration which permits the prosecution to trust habitually to compulsory self-disclosure as a source of proof must itself suffer morally thereby. The inclination develops to rely mainly upon such evidence, and to be satisfied with an incomplete investigation of the other sources. ${ }^{37}$

The police are not compelling the defendant to make a self-disclosure of any fact except that this is his voice. They have procured an independent witness to identify him as the culprit or to identify his voice as that of the culprit. No inclination has developed to rely on the defendant for evidence of his guilt. Investigation has produced another source. Thirdly, reference would be made to the fact that there is little or no difference between compelling a man to wear the same clothes worn by the perpetrator of the crime and compelling him to speak the same words that were spoken in the crime. This type of analysis has been used by the courts to justify compulsory fingerprints, physical examinations, and other like procedures. Finally, it would be contended that this practice is necessary in order for the police to carry out their primary obligation of apprehending lawbreakers. Without this practice, the police will be stymied in their prosecution of many violent crimes, such as rape or armed robbery.

Those who would argue that the elimination of the use of the "exact word identification" because it is contrary to the fifth amendment would assert that the testimonial compulsion test is inherently vague ${ }^{38}$ and offers no help at all in determining the applicability of the privilege in this situation. Application of this test, even if it is conceded to be valid in certain areas, is not valid here. The courts have stretched Justice Holmes' analysis of the privilege in Holt from the mere wearing of a blouse worn in a

37. 8 WIGMORE \& 2251, at 309.

38. The vagueness of the testimonial compulsion test is evident from the statement that compulsion occurs where the person asserting the privilege is proceeded against by a "form of process treating him as a witness (i.e., as a person appearing before the tribunal to furnish testimony in his moral responsibility for truth telling) ..." or where "he would be at any time liable to make oath to the ... authenticity or origin of the articles produced." 8 WIGMORE $\$ 2264$, at 363 . 
crime to such far-removed areas as bloodtesting and physical examinations of the accused's body. The extention of this conservative analysis of the privilege against self-incrimination is completely inconsistent with the present liberal philosophy of protecting the individual's rights during the criminal process. Underlying this argument would be the contention that it is impossible to validly justify the use of the exact words of the crime for identification purposes when mere inane statements would serve the same purpose. To argue that the witness is not able to make an accurate identification unless the exact words are used raises a serious question as to the witness' ability to make a valid identification at all. Most crimes which are adaptable to this type of identification procedure are of the face-to-face variety which involve either a show of force or the use of actual force and, therefore, are crimes which involve a great deal of emotional strain on the victim. To re-create this emotional strain in the mind of the victim would hamper his ability to make an objective identification and seriously prejudice the entire procedure against the defendant. $^{39}$

\section{The Lineup and the Right to Counsel}

The accused's right to counsel at a given time, and his right to have counsel retained for him where he is indigent, has been greatly expanded during the past six years $;^{40}$ but there has not been a single Supreme Court decision dealing with the right of the accused to have counsel present at a lineup. In July of this year, however, the Supreme Court granted certiorari in Gilbert v. California, ${ }^{41}$ a case concerned in part with whether the accused's right to counsel was violated when he was compelled to appear without benefit of counsel at a lineup which resulted in his identification by eyewitnesses who were shown unlawfully seized photographs of the defendant prior to their attendance at the lineup. In all probability, a decision of the Court with regard to the sixth amendment implications of the lineup will be shortly forthcoming.

Prior to 1963 there was no federally protected right to counsel in state prosecutions. In that year the Supreme Court held in Gideon v. Wainwright ${ }^{42}$ that the sixth amendment applied to the states through the due process clause of the fourteenth amendment. As a consequence of Gideon, the federal decisions relevant to the time at which a right to

39. It is admitted that this argument is not constitutional but evidentiary in nature, tending to relate only to the weight of the evidence. It is included because it is felt that it is a practical problem the Supreme Court would consider.

40. For treatment of the historical development, see Enker \& Elsen, Counsel for the Suspect, 49 Minn. L. REv. 47, 49 (1964); Herman, The Supreme Court and Restrictions on Police Interrogation, 25 OнIo ST. L.J. 449, 481 (1964); Developments in the Law - Confessions, 79 HARV. L. REV. 935, 996 (1966).

41. 63 Cal. 2d 690, 408 P.2d 365, 47 Cal. Rptr. 909 (1965), cert. granted sub nom. Gilbert v. California, 384 U.S. 985 (1966).

42. 372 U.S. 335 (1963). 
counsel accrues were also made applicable to the states. Under one line of cases a right to counsel exists at pre-trial arraignments where a protected right may be lost due to the accused's unawareness of certain procedural rules, ${ }^{43}$ and at pre-trial hearings before a judicial officer where statements may be made that can be admitted at trial. ${ }^{44}$ Another line of cases has extended the right to counsel to situations in which investigative techniques of the police are at issue. In Massiah $v$. United States ${ }^{\mathbf{4}}$ the Supreme Court declared that eliciting incriminating statements from a defendant after indictment without the presence of counsel is violative of the sixth amendment. Escobedo $v$. Illinois ${ }^{46}$ extended the rationale of Massiah to the point at which police investigation takes on an accusatorial focus directed at eliciting incriminating statements from the accused. In Miranda $v$. Arizona, ${ }^{47}$ decided in June of this year, the Supreme Court attempted to set out categorically the scope of right to counsel at the pretrial stage.

In Miranda, the Court focused on the right to counsel as a device to insure a free and intelligent exercise of one's fifth amendment right to remain silent:

The prosecutor may not use statements, whether exculpatory or inculpatory, stemming from custodial interrogation of the defendant unless it demonstrates the use of procedural safeguards effective to secure the privilege against self incrimination ... prior to any questioning ... [T] he person must be warned that he has a right to remain silent, that any statement he does make may be used as evidence against him, and that he has a right to presence of an attorney either retained or appointed. ${ }^{48}$

Following this rationale, a lineup procedure that merely requires the accused to stand in front of certain witnesses would not come within the Miranda decision, unless the accused's privilege against self-incrimination were violated. ${ }^{4 \theta}$ Previous analysis indicates that participation in the lineup to this extent, even though by compulsion, is not violative of the fifth amendment. ${ }^{50}$ A claim of a right to counsel in this instance would therefore be unfounded.

The use of voice identifications in connection with the lineup, however, presents a question closer to the scope of Miranda. In People $v$. $J$ uare $z^{51}$ the California Court of Appeals dealt with the validity of the use of a voice identification during a lineup in light of Miranda and

43. Hamilton v. Alabama, 368 U.S. 52 (1961). The Court held that where a defense could be waived if not raised at an arraignment, a right to counsel existed.

44. White v. Maryland, 373 U.S. 59 (1963) (per curiam).

45. 377 U.S. 201 (1964).

46. 378 U.S. 478 (1964).

47. Miranda v. United States, 384 U.S. 436 (1966).

48. Id. at 444 .

49. Gilbert v. United States, 35 U.S.L. WEEK 2170 (9th Cir. Oct. 16, 1966).

50. See text accompanying note 8 supra.

51. 52 Cal. Rptr. 556 (D.C. App. 1966). 
Schmerber. ${ }^{52}$ The court, adopting the traditional analysis of the fifth amendment privilege, ${ }^{53}$ equated voice identifications to the use of writing exemplars and concluded that no fifth amendment rights had been impaired. No distinction was made in Juarez between inane statements and the exact words spoken by the perpetrator of the crime. Granting the fact that there is no process of "interrogation" involved in compelling the accused to say the words of the crime, the question of whether this type of investigative conduct transcends the rationale of identification and enters into the area protected by the fifth amendment must be considered. If the Court were to make a distinction based on the character of words the accused is requested to speak, a right of counsel would accrue since a fifth amendment right would be at stake.

There are practical reasons for having counsel present at a lineup, aside from the constitutional issues presented. Since the identification will eventually be introduced into evidence, the reliability of the identification will be of prime importance. If the accused has counsel present at the lineup, counsel can take steps to make certain the lineup is conducted in a manner that is fundamentally fair to the accused. For example, counsel could probably act to correct a gross lack of similarity between the accused and the other parties in the lineup, or to prevent the police from pointing out the accused to the witness prior to the lineup. No concrete reason can be advanced for denying counsel permission to be present, and his presence will serve to attest to the fairness and integrity of the lineup as practiced in a particular jurisdiction.

\section{Illegal Arrest and the Evidentiary Fruits of the Police Lineup}

\section{A. The Problem}

In considering the fourth amendment's relationship to the lineup, a hypothetical will be employed to aid in the visualization of the initial problems presented.

A robbery of a liquor store was committed in the early hours of the morning on July 4, 1966. The culprit escaped leaving the liquor store owner bound. Investigation at the scene of the crime turned up no real clues, but a screening of police files revealed eight possible suspects who had a modus operandi similar to that employed in the robbery. The local area was canvassed, and four of the eight were located and brought to the station house. No other evidence against any of the four existed, and it is assumed their arrest lacked probable cause. A lineup was held and a positive identification made. On the basis of this identification, the police obtained a search warrant from the local magistrate. The home of the accused was searched and the money taken was recovered.

52. 384 U.S. 757 (1966).

53. See text accompanying notes 31-34 supra. 
Three basic issues arise:

1. Can the victim testify at the trial with regard to the lineup identification?

2. Can the victim make an in-court identification?

3. Can the stolen money be introduced into evidence at the trial?

\section{B. The Rights of the Accused Under the Fourth Amendment}

Citizens of the United States were initially protected from federal intrusions into their privacy by the fourth amendment. ${ }^{54}$ However, it was not until 1914 in Weeks v. United States ${ }^{55}$ that the Supreme Court, acting in its supervisory capacity over the federal courts, initiated an exclusionary rule of evidence as an attempt to insure the effectuation of this right. The states, on the other hand, were not considered bound by the fourth amendment until the Court's decision in Wolf $v$. Colorado ${ }^{50}$ in 1949. But while $W$ olf held that the fourth amendment was applicable to the states, it did not result in the adoption of the exclusionary rule. The Court concluded that only the basic right was within the concept of "ordered liberty" and applicable to the states through the due process clause of the fourteenth amendment. The parallel to Weeks in the federal genesis occurred in Mapp $v$. Ohio ${ }^{57}$ where the Court reconsidered $W$ olf, and held that the exclusionary rule was part and parcel of the fourth amendment and should be applied in state prosecutions. In $\mathrm{Ker} v$. California $^{\mathbf{5 8}}$ it was held that, in determining violations of the fourth amendment, the states would be required to meet minimum federal standards. Justice Clark writing for the majority in Mapp set out the fundamental reason for incorporating the exclusionary rule into the fourth amendment guarantee :

Were it otherwise, then just as without the Weeks rule the assurance against unreasonable federal searches and seizures would be "a form of words," valueless and undeserving of mention in a perpetual charter of inestimable human liberties, so too, without that rule the freedom from state invasions of privacy would be so ephemeral and so neatly severed from its conceptual nexus with the freedom from all brutish means of coercing evidence as not to merit this Court's high regard as a freedom "implicit in the concept of ordered liberty."

54. The right of the people to be secure in their persons, houses, papers and effects, against unreasonable searches and seizures, shall not be violated and no Warrants shall issue, but upon probable cause, supported by Oath or affirmation, and particularly describing the place to be searched, and the persons or things to be seized.

U.S. Const. amend. IV.

55. 235 U.S. 695 (1914).

56. 338 U.S. 25 (1949).

57. 367 U.S. 643 (1961).

58. 374 U.S. 23 (1963).

59. Mapp v. Ohio, 367 U.S. 643, 655 (1961). 
But while protection of the right of privacy is the ultimate purpose of the exclusionary rule, several more precise reasons have been posited as underlying bases : ${ }^{80}$

1. Providing the victim of a violation of the fourth amendment with an adequate remedy;

2. Preventing a governmental police branch from profiting, by way of conviction, from its illegal conduct;

3. Preserving the integrity of the judicial processes; and

4. Serving as a deterrent to future illegal conduct by the police.

Almost immediately following the adoption of the exclusionary rule at the federal level in Weeks, the Court was faced with the problem of defining the scope of the rule. In Silverthorne Lumber Co. v. United States, ${ }^{61} \mathrm{Mr}$. Justice Holmes asserted that "the essence of the provision forbidding the acquisition of evidence in a certain way is that not merely evidence so acquired shall not be used, but that it shall not be used at all." 62 Not only the direct products of action violative of the fourth amendment would be excluded, but indirect evidentiary fruits as well.

Verbal statements had not been subject to exclusion on fourth amendment grounds until Wong Sun v. United States. ${ }^{\mathbf{6}}$ In that case the exclusionary rule was applied to certain statements and to real evidence related in a "but for" manner to the illegal arrest. The Court in determining what evidence should be excluded, adopted a test espoused by Professor Maguire: "The more apt question in such a case is whether, granting an establishment of the primary illegality, the evidence to which instant objec-

60. Allen, The Wolf Case: Search and Seizure, Federalism, and Civil Libertics, 44 ILL. L. REv. 1, 16-30 (1951) ; Kamisar, Illegal Searches or Seizures and Contemporaneous Incriminating Statements: $A$ Neglected Area of the Criminal Procedure, 1961 U. ILl. L.F. 78, 92; Paulson, The Exclusionary Rule and Misconduct by Police, $52 \mathrm{~J}$. Crim. L., C. \& P.S. 255 (1961) ; Comment, 57 Colum. L. Rev. 1159, 1164-70 (1961). 61. 251 U.S. 390 (1920).

62. Id. at 392 .

63. 371 U.S. 471 (1963). There has been a great deal of controversy with regard to whether Wong Sun rests on fourth amendment grounds. Some courts, seizing on the oppressive circumstances under which the statements were made, have interpreted Wong Sun to be an application of the coerced confession rule of the fourteenth amendment. Dailey v. State, $239 \mathrm{Md}$. 596, 212 A.2d 257 (1965). Other courts have held that $W$ ong Sun rests on fourth amendment grounds, and apply the exclusionary rule even where no oppressive circumstances are found. People v. Haven, 59 Cal. 2d 713, 381 P.2d 927, 31 Cal. Rptr. 47 (1963).

Granting that Wong Sun rests on fourth amendment grounds, a question still exists as to whether it is applicable to the states through the due process clause of the fourteenth amendment, or is merely based on the supervisory power of the Supreme Court over the federal courts. In light of Ker v. California, 374 U.S. 23 (1963), which made the fourth amendment applicable to the states in toto, it appears that Wong Sun would also be binding on the states. The Supreme Court indicated the correctness of this position in Traub v. Connecticut, 374 U.S. 493 (1963) (per curiam), when it vacated judgment in a state search and seizure case and remanded the case for reconsideration in light of Wong Sun and Ker.

See for an analysis of this question: Broeder, Wong Sunv. United States: A Study in Faith and Hope, 42 NEB. L. Rev. 485, 557 (1963); Herman, The Supreme Court and Restrictions on Police Interrogation, 25 Онго S'. L.J. 449, 459 (1964). 
tion is made has been come at by exploitation of that illegality or instead by means sufficiently distinguishable to be purged of the primary taint."04

The test adopted in Wong Sun is designed to exclude direct and indirect fruits of the illegal conduct, in order to effectuate the primary purpose of the exclusionary rule - deterrence. The test does not result in the exclusion of all evidence related in a but for manner to the illegality, but is only applied where a deterrent effect will be realized. The Court has recognized that exclusion will be ineffective in two instances. If the prosecution can prove that the evidence was or would have been discovered by independent sources, it will be admissible. ${ }^{65}$ Furthermore, where the evidence is so attenuated in causal relation from the initial violation as to be considered free of the original taint of illegality, the rule will not be applied. $^{06}$ In order to adequately deter, a remedy must make violation of the rule an undesirable course of conduct. To limit the rule to direct evidentiary products of an illegal arrest or search would fail to adequately deter illegal police conduct. Indirect evidence can be of equal value or, in some cases, of even greater value than the initial fruits of the illegality. Therefore, if the exclusionary rule were limited to direct products its effect would be minimized, if not negated.

\section{The Fourth Amendment and the Lineup}

The contentions of the defendant in the above hypothetical, in attempting to secure the exclusion of the lineup identification, would be based on an application of the exclusionary rule not yet considered by the Supreme Court. Prior precedent has focused on the exclusion of real evidence, verbal statements and evidentiary fruits resulting from an illegal search or arrest. A lineup presents a unique circumstance in that neither real evidence nor verbal statements of the accused are the immediate result of the illegality. Rather, the identification of the accused by a witness or a victim results. Application of the exclusionary rule to the lineup situation will be viewed in light of the rationale of the rule, its social consequences, and the remedial steps which might be utilized to avoid the problem.

The California Court of Appeals recently considered a case similar to the hypothetical presented above in People $v$. Watson. ${ }^{\mathbf{6 7}}$ The court focused on the exploitation test of $W o n g \operatorname{Sun}^{68}$ in holding that testimony relevant to a lineup conducted after an illegal arrest should not be excluded. Crucial to the court's decision was the fact that the arrest was made in good faith and that the lineup did not amount to an exploitation

64. Id. at 488 (quoting MAGUIRE, op. cit. supra note $23, \S 5: 07$ at 221 ).

65. Wong Sun v. United States, 371 U.S. 471,487 (1963); Silverthorne Lumber Co. v. United States, 251 U.S. 385, 392 (1920) (dicta).

66. Wong Sun v. United States, 371 U.S. 471, 491 (1963) ; Nardone v. United States, 308 U.S. 338, 341 (1939) (dicta).

67. 234 Cal. App. 203, 44 Cal. Rptr. 306 (1965).

68. Wong Sun v. United States, 371 U.S. 471 (1963). 
of the illegal arrest. The Watson interpretation of the exploitation test appears to be based on the subjective intent of the arresting officers rather than the position of the accused in the lineup situation. The court did infer, however, that if the test were applicable, exclusion would be the appropriate remedy.

In Gatlin v. United States, ${ }^{69}$ the District of Columbia Court of Appeals considered the admissibility of a lineup identification obtained subsequent to an illegal arrest. The court held that a sufficient link existed between the illegality and the evidence sought to be introduced, and excluded testimony relevant to the lineup on the basis of Wong Sun. But while the Watson and Gatlin courts agree that the exclusionary rule should apply if exploitation of the illegal arrest is found, they differ in their concept of that standard. The Gatlin court used the interpretation most in line with the purposes of the rule and its underlying rationale by seeing a need for a deterrent to protect the fourth amendment rights of the individual in the situation presented. The Watson decision, on the other hand, turned on the idea that good faith illegal police conduct cannot be deterred. This view disregards the deterrent effect accomplished by requiring police to weigh more heavily the rights guaranteed a suspect by the fourth amendment.

In State v. Hodgson ${ }^{70}$ the Supreme Court of New Jersey dealt hypothetically with the consequences of a lineup identification following an illegal arrest. The court, noting that the defendant had been in custody for twelve hours prior to the lineup, concluded "that the link between any illegality in the arrest and the later evidence was so attenuated that it can not serve to taint the evidence." 71 This application of the attenuation concept was based primarily on the lack of relation between the illegal arrest and the lineup identification in point of time. In this respect, the court's conclusions are unjustified. To allow a mere interim of hours to be dispositive in the denial of the application of the exclusionary rule is paying mere lip service to the rule. A pertinent point must be kept in mind - there is no issue with regard to the voluntariness or involuntariness of the accused in the lineup situation. An arrestee is forced to participate in a lineup, and a mere passing of hours in no way lessens the relationship between illegal police conduct and the lineup identification. Furthermore, the effect of an illegal arrest becomes more aggravated, rather than lessened, as detention continues.

In Payne $v$. United States ${ }^{\mathbf{7 2}}$ an issue was raised with regard to whether a trial court ${ }^{73}$ had erred in failing to sustain a motion to bar an in-court identification obtained as a result of a lineup. The lineup had been conducted while the accused was in custody in violation of rule 5(a)

69. Gatlin v. United States, 326 F.2d 666 (D.C. Cir. 1963).

70. 44 N.J. 151, 207 A.2d 542 (1965).

71. Id. at 156,207 A.2d at 545 .

72. 294 F.2d 723 (D.C. Cir. 1961), cert. denied, 368 U.S. 883 (1961).

73. The lower court excluded testimony relevant to the actual lineup identification, but allowed the in-court identification. 
of the Federal Rules of Criminal Procedure. ${ }^{74}$ Circuit Judge Washington, speaking for the full court, affirmed the trial court's decision : "The consequence of accepting the appellants contention in the present situation would be that Warren (the identifying witness) would be forever precluded from testifying against Payne... . Such a result is unthinkable."75 There is a clear distinction between the situation in Payne and that presented by an illegal arrest. The Payne court went to great lengths to emphasize the fact that the arrest of the accused was constitutional, even though rule 5 (a) had been violated. Rule $5(\mathrm{a})$ is designed to bring a suspect before a magistrate as soon as reasonably possible in order to insure the protection of his fifth amendment rights; however, in the illegal arrest case, there is a violation of the constitutional rights of the accused $a b$ initio. Payne, when viewed on its facts, has no relevence on the illegal arrest situation, even though the Hodgson and Watson courts treated it as a proper precedent in the area.

The Supreme Court has not faced a situation similar to that posed in the hypothetical, and the existing case law seems to be at odds. Some cases draw on the liberal philosophy and ideals of the cases in analogous areas, while others seek to limit cases to their facts and find in favor of the prosecution. The Supreme Court, in considering the lineup as it relates to the fourth amendment, will not be faced with precedent categorically demanding a given decision. Rather, it will be in the position of weighing the conflicting interests of the police, the individual, and society as a whole.

\section{How Would the Supreme Court Decide?}

1. Admission of a Lineup Identification Obtained Subsequent to an Illegal Arrest. ${ }^{76}$ - It would appear that, if the rationale of prior Supreme

74. FED. R. CRIM. P. 5 (a) :

An officer making an arrest under a warrant issued upon complaint or any person making an arrest without a warrant shall take the arrested person without unnecessary delay before the nearest available commissioner or before any other nearby officer empowered to commit persons charged with offenses against the laws of the United States. . .

McNabb v. United States, 318 U.S. 323 (1943), and Mallory v. United States, 354 U.S. 449 (1957), have made the exclusionary rule the remedy for violations of this rule.

75. Payne v. United States, 294 F.2d 723 (D.C. Cir. 1961), cert. denied, 368 U.S. 883 (1961).

76. The following analysis is based on the constitutional challenge to the introduction of testimony relevant to the lineup after an illegal arrest. It should be noted, however, that the hearsay rule will generally exclude prior consistent statements that are made out of court. Prior consistent statements will be admitted only to corroborate the in-court identification of a witness whose reliability has been challenged. When such evidence is admitted, there is a diversity as to whether the jury may consider it only on the issue of credibility, or whether it can also be considered as substantive evidence. 4 WIGMORE $\S \S 1130,1134$ (3d ed. 1940).

Some state courts have recently taken the situation presented from under the hearsay rule, because they feel the hearsay dangers do not exist where prior consistent statements are offered in evidence. In these jurisdictions, the testimony may be admitted as substantive evidence, notwithstanding the fact that it is not introduced to corroborate an in-court identification. People v. Gould, 54 Cal. 2d 621, 354 P.2d 865, 7 Cal. Rptr. 273 (1960). 
Court decisions in the fourth amendment area were applied to a situation in which a lineup identification is made subsequent to an illegal arrest, and evidence of this sought to be introduced at trial, it should be excluded. Yet a decision of this kind would have serious social ramifications, since it would curtail the use of a police practice generally considered legitimate. One possible basis for the denial of a motion to exclude would involve the adoption of an approach similar to that taken in Smith $v$. United States. ${ }^{77}$ In that case a confession, and real evidence resulting from it, were excluded as a violation of rule 5(a) of the Federal Rules of Criminal Procedure, but the court refused to exclude the testimony of a witness found as a result of the confession, asserting that the testimony represented the free choice of an independent actor. A similar argument might be made with regard to the lineup. However, Watson ${ }^{78}$ by inference, Gatlin ${ }^{79}$ on its holding, and the lower court opinion in Payne $^{80}$ give strength to the view that if an exploitation of an illegal arrest is found, the testimony should be excluded. Furthermore, there is a critical distinction between the nature of the illegality in Smith and the fact that there is an $a b$ initio constitutional violation presented by an illegal arrest.

In light of the constitutional violation does the rationale of the exclusionary rule demand exclusion? Some deterrent is certainly required to discourage the use of "dragnet" procedures by the police. Even if there is a good faith arrest, there is a need to deter police from making rash arrests which interfere with an individual's fourth amendment rights to the same extent as the "dragnet." To permit the police to profit from their illegal conduct would seem contrary to the rationale of the cases. If the exclusionary rule is not applied, the accused has no adequate remedy. Finally, the judiciary, by not excluding such evidence, would be in fact sanctioning the violation.

There are ample grounds on which to conclude that the exclusionary rule should be applied to a lineup conducted subsequent to an illegal arrest. Whether there are grounds for distinguishing prior precedents favoring this conclusion is debatable. The question more appropriately is whether there is any adequate reason to attempt to make such a distinction.

2. Admission of In-Court Identifications Made by Witnesses Who Have Made Initial Identifications at Lineups Subsequent to an Illegal Arrest. - At first impression, most persons would react similarly to Judge Washington in the Payne case when he asserted that not permitting witnesses who have made lineup identifications to repeat these identifications

77. 324 F.2d 879 (D.C. Cir. 1963).

78. People v. Watson, 234 Cal. App. 203, 44 Cal. Rptr. 306 (1965).

79. Gatlin v. United States, 326 F.2d 666 (D.C. Cir. 1963).

80. Payne v. United States, 294 F.2d 723 (D.C. Cir. 1961). 
in court would be unthinkable.81 However, reflection on the matter will lead to a less dogmatic, and perhaps even contrary conclusion. A most serious problem is presented by the admission of an in-court identification where the initial lineup identification was unconstitutional. In People v. Watson ${ }^{82}$ the court did not rule on the exclusion of the lineup identification because the in-court identification was so condemning that exclusion of testimony relevent to the lineup was of no real consequence. Obviously, if the exclusionary rule is to have an effect in this situation, it must apply to in-court testimony as well as testimony regarding the lineup identification. To exclude one and not the other is merely a token act. Police in a difficult case could concede the loss of the lineup testimony to reap the harvest of the in-court identification.

Of course, this seems a remedy even more harsh than that criticized by then Judge Cardozo in People v. Defore ${ }^{83}$ when he stated that, "the criminal is to go free because the constable has blundered." But the criminal goes free only to insure a higher value - the right of privacy. Is this result any more stark than the exclusion of a trustworthy confession obtained after a legal arrest, as dictated by Miranda $v$. Arizona $?^{\text {84 }}$ The total bar with regard to identification evidence would adequately deter illicit police conduct, insure an adequate remedy for the accused, and protect the integrity of the judiciary.

3. Admission of Real Evidence Seized Under a Valid Search Warrant Obtained as a Result of a Lineup Conducted Subsequent to an Illegal Arrest. - In our hypothetical defendant's arrest lacked probable cause and was based merely on suspicion. By illegally arresting the defendant and forcing him to participate in a lineup, the police acquired grounds for the search warrant. Is this not a most direct exploitation of the illegal arrest since the real evidence they seek pursuant to the warrant is almost assured to provide the basis for conviction? Could the Court deny the application of the exclusionary rule?

No search of the defendant's house could have been conducted prior to the illegal arrest. What in the interim could so attenuate this real evidence so as to make it admissible? No independent source is involved and the causal relation is direct. Again the deterrent rationale seems clearly to demand exclusion. To admit this evidence might encourage the police, in a given case, to give up the testimony of the witness for the real evidence. Our Constitution and its demands are not to be employed in a chess match where the police give up a knight to capture a queen. The law is clear - obey the fourth amendment. Is this too great a burden for the police to shoulder?
81. Id. at 727.
82. People v. Watson, 234 Cal. App. 203, 44 Cal. Rptr. 306 (1965).
83. 242 N.Y. 13,150 N.E. 585 (1926).
84. Miranda v. Arizona, 384 U.S. 436 (1966). 


\section{E. The Effect}

It is easy to see why public reaction to an actual case similar to our hypothetical would be adamantly contrary. How blatant could a crime be? Yet the victim is precluded from testifying in court, and the money obtained pursuant to the search cannot be introduced at trial since the arrest of the accused was illegal. Society is indeed paying a heavy price.

A sanction, however, must be commensurate to and weighed against the right it is designed to protect and the means available to insure its protection. Because the right to privacy has a close association with the fundamental liberty of the person, it ranks as a most noble right. Granting the necessity of society to protect itself from the criminal, there lies a prior necessity in the protection of the individual citizen from unauthorized extensions of police authority. When squarely faced, all the rule does is to provide a deterrent sanction for violations of the law. This is not an overbearing duty to place on government officials in view of the fact that it is their sworn duty to aid in insuring this exact result.

Much of the initial distaste brought about by the application of the fourth amendment and its sanctions to the lineup situation can be dispelled by reflection on what steps could be taken by police to prevent imposition of the exclusionary rule. The "dragnet" is clearly an illegal practice that should not be allowed and, therefore, the resulting exclusion of all the evidence is warranted. In the good faith arrest situations, the adoption of a rule similar to the $M c N a b b-M a l l o r y{ }^{85}$ rule would insure the validity of the lineup and its products. A magistrate would certify that probable cause existed, thereby eliminating the possible consequence of later exclusion. All that would be required is that the lineup be delayed a short period of time in order to have this ruling made. This procedure would protect the rights of the individual as well as the interests of the police and society.

\section{The Lineup and the Equal Protection Clause of the Fourteenth Amendment}

In Philadelphia, when persons indicted for criminal offenses cannot make bail they are committed to the Philadelphia Prisons Detention Center to await trial. These persons are sometimes suspected of having committed unsolved crimes which are totally distinct from the offenses for which they were indicted. In these circumstances, if there are witnesses to the crime who may be able to identify the culprit, the police arrange a lineup. The use of the lineup in these cases may involve serious legal problems, for if the suspect had been able to make bail, he could not be forced to take part in such a lineup unless the police actually arrested him for the unsolved crime. What will be the constitutional effect of the

85. See note 74 supra. 
police placing a non-bail suspect in a lineup where reasonable grounds for his arrest do not exist, and he could not be taken into custody and placed in the lineup if he were free on bail?

On occasion, suspects in custody have objected to being forced to take part in lineup procedures. In 1964 two suspects brought an action in the District Court for the Eastern District of Pennsylvania to enjoin the police from placing them in a lineup. ${ }^{80}$ Judge Freedman, then District Judge, granted a temporary injunction, finding that a compulsory lineup of the unbailed suspect would amount "to a material distinction between those who enter bail and those - equally presumed to be innocent - who do not,"87 and that there was "substantial merit"88 in the claim that placing these suspects in lineups would constitute an invidious discrimination depriving them of the equal protection of the laws guaranteed by the fourteenth amendment. ${ }^{89}$ However, in 1965, when a number of suspects, in custody under the same circumstances, brought similar actions to enjoin the police from placing them in lineups, District Judge Luongo denied injunctive relief, ${ }^{90}$ holding that the discrimination against non-bail suspects was not an invidious discrimination in the constitutional sense, ${ }^{91}$ since it had for its basis a reasonable classification, "the classification of jail versus bail."92 Pointing out that the eighth amendment provides for such a classification of criminal suspects, Judge Luongo argued that those in one class - confinement - are discriminated against in many ways: "Confinement carries with it a suspension of or a restriction upon the exercise of most of the rights of free men, not the least of which is liberty itself."93 In June of 1965, in Rigney $v$. Hendrick, ${ }^{94}$ the United States Court of Appeals for the Third Circuit affirmed the decisions of Judge Luongo:

Admittedly, there is a classification between those who can and those who cannot make bail. The Constitution, however, permits such a classification, and any differences here, arise solely because of the inherent characteristics of confinement and cannot constitute invidious discrimination. ${ }^{95}$

86. Butler v. Crumlish, 229 F. Supp. 565 (E.D. Pa. 1964).

87. Id. at 567 .

88. Butler v. Crumlish, 229 F. Supp. 565, 568 (E.D. Pa. 1964).

89. Plaintiffs had been freed on bail when the case came up for final hearing. The defendants there assured the court that if the plaintiffs ever again came into the custody of the authorities, they would be allowed to communicate with counsel and seek injunctive relief before being placed into a lineup. Judge Freedman held that the threat of the lineup was too remote and indefinite and denied the final injunction. Butler v. Crumlish, 237 F. Supp. 58 (E.D. Pa. 1964). Thus he did not not actually decide the constitutional question.

90. Rigney v. Hendrick, Civil No. 37791 (E.D. Pa., April 7, 1965); Johnson v. Hendrick, Civil No. 37657 (E.D. Pa., April 14, 1965); Morris v. Crumlish, 239 F. Supp. 498 (E.D. Pa. 1965).

91. Douglas v. California, 372 U.S. 353, 356 (1963).

92. Morris v. Crumlish, 239 F. Supp. 498, 500 (E.D. Pa. 1965).

93. Ibid.

94. 355 F.2d 710 (3d Cir. 1965), cert. denied, 384 U.S. 975 (1966). The question had become moot, since Rigney, the petitioner, had been released on bail.

95. Id. at 715. On petition for rehearing, five judges voted against, and three voted for a rehearing en banc, and the petition was denied. 
The concept that there is a boundary about each individual's private life, beyond which neither the state nor other individuals may freely enter, is so basic that many of our specific guarantees of liberty spring from it. "The security of one's privacy against arbitrary intrusion by the police ... is basic to a free society, [and] ... implicit in 'the concept of ordered liberty'." 96 In Pennsylvania, the police may arrest a person without a warrant only if the arresting officer has reasonable grounds to believe that a felony has been committed and that the person he contemplates arresting is the felon. ${ }^{97}$ The bailed suspect, therefore, is protected against police interference with his privacy by this concept of reasonableness, since short of an actual arrest he cannot be placed in a lineup against his will. The suspect who is held in the custody of the authorities without bail should receive no less protection. If a man is forced to take part in a lineup because he is within the control of the authorities, when another suspect, identical in every way except in wealth, can avoid the lineup because of his ability to post bail, an invidious ${ }^{88}$ discrimination exists in the sense of the equal protection clause. Whether or not this is the law is not at all clear from the opinion of the Court of Appeals in Rigney.

Rigney $v$. Hendrick $k^{99}$ was a consolidation of the appeals of six indigent suspects who, while in custody at the Detention Center in Philadelphia, were placed in lineups for crimes distinct from those for which they were being held. The majority of the court singled out the facts pertinent to one appellant, Roosevelt Morris, ${ }^{100}$ saying that the facts were substantially the same in all the cases, and briefly sketched enough key facts to show that there were reasonable grounds for an arrest of that suspect. ${ }^{101}$ By taking this approach, the court averted the problem of deciding the constitutionality of a lineup of a suspect in the absence of probable cause.

In his dissent from the majority's denial of the petition for rehearing, Judge Freedman argued incisively that if there were no problem of a lack of probable cause, "since the appellants conceded that a police lineup would be permissible if they had been arrested on the new charges, their contention amounted to no more than an insistence on the formality of a new arrest to obtain custody over a defendant who had already been

96. Wolf v. Colorado, 338 U.S. 25, 27 (1949).

97. See note, 100 U. PA. L. REV. 1182 (1952) for a detailed review of the cases.

98. The Merriam-Webster New InTERnational Dictionary (2d ed. 1959) defines "invidious" as something "unjustly and irritatingly discriminating."

99. Rigney v. Hendrick, 355 F.2d 710 (3d Cir. 1965), cert. denied, 384 U.S. 975 (1966).

100. This was the only opinion which was reported below. See Morris v. Crumlish, 239 F. Supp. 498 (E.D. Pa. 1965).

101. Morris was awaiting trial for burglary and other related offenses. After his indictment, the victim of a burglary and rape not connected with the crimes included in the indictment, identified some items, which were discovered in Morris' possession at the time of his arrest, as her property. In addition, the suspect's modus operandi was similar to that employed against this victim. Rigney v. Hendrick, 355 F.2d 710, 711 (3d Cir. 1965). 
arrested on an earlier offense and was then in confinement because of his inability to furnish bail."102 Furthermore, Rigney, the only appellant who petitioned the court for a rehearing, claimed in his petition that the police had no probable cause for arresting him for the lineup-connected offense. ${ }^{103}$

The inequalities involved in making a distinction between bailed and unbailed suspects in the lineup situation cannot be excused by relating it to the permissible classification. That classification sanctions its legitimate progeny, and they are many. Fundamental freedoms may be cut off by the necessities of prison life, but only when this result is the unavoidable consequence of that life. The administration of a penal institution in no way necessitates the lineup of suspects who are held in that institution solely because they are unable to make bail.

\section{ViI. The Lineup as a Product of Police Coercion}

There are two related patterns of argument which challenge the basic constitutionality of police lineups. On one hand, it can be argued that the fact that a suspect must stand, speak, or assume a stance compels him to be a witness against himself. It is a different question, however, to ask whether the fact that his participation is the product of coercion makes this such an impermissible police activity as to clash with our basic concepts of ordered liberty ${ }^{104}$ and result in a violation of the due process clause. Judge Freedman, dissenting in Rigney $v$. Hendrick, ${ }^{105}$ argued that the court should "examine the due process of law contention that all lineups are unconstitutional in any event because they coerce the defendant into an involuntary participation in his criminal prosecution."106

The United States Supreme Court, in Rochin $v$. California, ${ }^{107}$ developed the principle that the very character of police behavior, of "methods too close to the rack and the screw,"108 could taint even socalled "real evidence,"109 forcing its exclusion. In that case, law enforcement officers first "jumped upon" the accused and tried physically to remove morphine capsules from his mouth. When these efforts proved unsuccessful, an emetic solution was forced into the accused's stomach. The Court, finding the conduct of the officers so extreme as to shock the conscience, held that the due process clause had been violated and that the evidence obtained was inadmissible. Critical to a proper evaluation of Rochin is the fact that the police officers violated the fourth amendment by unlawfully breaking into and entering defendant's room. ${ }^{110}$ But had

102. Id. at 716 .

103. Rigney v. Hendrick, 355 F.2d 710, 719 (3d Cir. 1965).

104. Palko v. Connecticut, 302 U.S. 319,325 (1937).

105. Rigney v. Hendrick, 355 F.2d 710 (3d Cir. 1965).

106. Id. at 718 .

107. 342 U.S. 165 (1952).

108. Id. at 172 .

109. Rochin v. California, 342 U.S. 165, 166 (1952).

110. People v. Rochin, 101 Cal. App. 2d 140, 143, 225 P.2d 1, 3 (1950). 
Rochin been treated as simply a garden variety search and seizure case, the federal policy of exclusion would not have been carried over against the state through the fourteenth amendment. ${ }^{111}$ The rationale of coercion was the new ingredient which set Rochin apart, and resulted in the exclusionary rule being applied to a state prosecution in a narrow circumstance.

The reasoning of the Supreme Court in Rochin should not be exaggerated beyond its proper factual framework, however. The police had so overstepped their rightful authority in that case that the Court found their conduct shocking to its conscience. In Schmerber v. California112 the Court implicitly recognized that, in instances of legitimate investigative work, the police have a clear right to use coercion within reasonable limits. In that case a police officer ordered a blood sample extracted from a suspect against his will. While recognizing that the evidence was the product of compulsion, the Court nevertheless held it to be admissible in a trial for the offense of driving while intoxicated.

Realistically, any right of the police would become meaningless if, merely by resisting, any suspect could choke off that right with an argument based upon coercion. If the police may take a sample of blood in a proper case, they must have the authority to compel the taking. Similarly, the lineup necessarily involves an element of compulsion. In Philadelphia, for example, while prison authorities will not physically compel a suspect to appear at a post commitment lineup, ${ }^{113}$ the threat of solitary confinement - the key to enforcing the order of the day in general prison life - is utilized to "encourage" prisoners to participate. The fact that pressures are brought to bear on suspects should not, in and of itself, make the whole lineup procedure unconstitutional, where the pressures employed are fair and reasonable in relation to the social usefulness of the lineup.

\section{A Model Lineup Procedure}

In order to avoid the possible consequences of the foregoing discussion, a model lineup procedure is submitted which is clearly within the various constitutional guarantees involved. Additional suggestions are incorporated to insure the maximum reliability of a witness identification.

1. All accused persons should be brought before a magistrate for a judicial determination of probable cause prior to being placed in a lineup.

2. Once in a lineup, the accused should be requested to recite only inane words. (For example, the police may ask the accused to read from the sports page of a local newspaper.) No request should be made to

111. The key case was still Wolf v. Colorado, 338 U.S. 25 (1949).

112. 384 U.S. 757 (1966).

113. See Testimony of E. J. Hendrick, Superintendent of the Philadelphia Detention Center, Record, Rigney v. Hendrick, Civil No. 37791 (E.D. Pa., April 7, 1965). 
speak the words allegedly said by the culprit at the time of the crime. No questioning should be done unless counsel is present or a valid waiver has been made.

3. The utmost effort should be made to have persons of similar characteristics in the lineup. Prior to the lineup the accused should not be identified as the person arrested for the crime. Both of these measures are designed to result in a reliable identification that would be as effective as possible at trial.

4. If possible, counsel should be present. A photograph of the lineup should be taken for submission to the jury as evidence of the reliability of the witnesses' identification.

5. If the accused is held after bail is set because of his indigency, no lineup should be held for other crimes unless sufficient evidence exists in the hands of police to constitute probable cause for arrest for the lineupconnected offense.

Thomas Edward Byrne

Marc B. Kaplin

Walter John Taggart 